\title{
Children's informed consent to treatment: is the law an ass?
}

\author{
Donna Dickenson The Open University, Milton Keynes
}

In England and Wales many practitioners and philosophers are profoundly disturbed by the loud clash between statute and case law regarding children's consent to medical treatment. Although only recently statute law appeared to be giving children more rights, case law now gives them fewer and fewer choices regarding their own treatment.

Essentially, children and young people under eighteen now have no right to refuse treatment, although English law kindly allows them to consent to whatever doctors propose. But it seems obvious that the power to give consent must also mean the power to withhold consent. Otherwise the right to consent would seem to be no more than the right to agree with the medical practitioner (1).

In the Court of Appeal judgement on the $W$ case (2), a sixteen-year-old anorexic girl, who was accepting treatment that was keeping her weight low but stable, was transferred to a clinic where she would be force-fed, although she refused consent. Here and in an earlier case, $\operatorname{Re} R(3)$, involving a fifteen-year-old girl who was given anti-psychotic drugs against her will, the court held that even competent minors could never refuse treatment if someone with parental responsibility consented to it.

In contrast, the Court of Appeal has held that doctors had no authorisation to force-feed a 37-yearold woman suffering from anorexia nervosa (4), quashing a High Court ruling allowing treatment without consent. Another recent example, $\operatorname{Re} C(5)$, reiterated the absolute right of even mentally ill adults to determine what happens to their own bodies. Here a chronic paranoid schizophrenic patient with an IQ of 70 refused amputation of a gangrenous leg, under his twin delusions that staff at his secure hospital habitually tortured him, and that he himself was a world-renowned physician with power to cure diseased limbs. The doctors emphasised that $C$ had only a 15 per cent chance of survival without the amputation, and argued that his schizophrenia produced incongruity of affect which marred his risk appraisal. But the court held that C's competence in other areas, such as personal finances, made him competent to refuse consent.

Compare $R$, in which Lord Donaldson held that a young person with uneven mental capacity could never be said to be competent. The principle of competence is rebuttable for adults, but the principle of incompetence does not appear to be rebuttable for young people. They have no right to refuse consent, whether or not judged competent.

And yet children as young as 10 can now be held criminally responsible for their actions. The longstanding principle that a child between 10 and 14 was presumed to be doli incapax, incapable of an injury - unless the prosecution specifically proved otherwise - was overturned in March 1994 (6). Children and young people now 'enjoy' responsibility without rights. In medical law muscular paternalism holds sway; in the criminal law, moral panic against embryonic yobs.

Disappointment and disillusion with the attitude of the English courts is particularly marked because practitioners had thought the law was finally beginning to give more weight to children's wishes. The Children Act 1989 (7), which came into force on 14 October 1991, explicitly incorporated the ascertainable wishes and feelings of the child into decision-making. The Act in turn built on a previous precedent, the Gillick case (8), which established that the child's full consent to examination, treatment, or assessment is required if he or she is of sufficient understanding to make an informed decision' (8). But in $R e$ W the court held that it could override the wishes of a minor, whether 'Gillick competent' or not.

Children's rights advocates now complain that 'judges are increasingly reluctant even to hear young people's views, let alone take them seriously', as David Hodgson of the Children's Rights Officers' Association puts it. 'Overall, the impression is that the child's testimony is only considered credible when it is self-incriminating' (9).

When courts override young people's refusal of consent to treatment, are they saying that adolescents are more irrational than adults (10)? The criminal law appears not to view youthful irrationality as any excuse, with the abolition of the doli incapax presumption. But might civil courts still be unwilling to let young people refuse treatment, particularly in matters of life and death, because their refusal appears irrational? 
If so, why not forbid adults to refuse potentially life-saving treatment, too? After all, if it is irrational to refuse life-saving treatment, it is no less so for adults than for children, although it may be particularly heart-wrenching to see a young person turn away from life.

Actually, neither $\mathrm{R}$ nor $\mathrm{W}$ was demonstrating irrationality or refusing life-saving treatment. $R$ had considered the side-effects of anti-psychotic drugs and found them unacceptable. She was merely demonstrating a different assessment of risk. The court argued deductively that a girl diagnosed as psychotic was at best intermittently rational, that intermittent rationality was not true rationality, and that therefore her reasoning processes were bound to be faulty.

W was not refusing all treatment: she wanted to stay in her existing treatment programme for anorexia nervosa, and had a body of experts behind her wish, the clinicians at her preferred centre. Nor had she given inadequate reflection to her potentially fatal condition; her condition was stable, although her weight low, until the court case began. Indeed, one might argue that it was the stress of the case itself which produced the supposed clinical imperative, force-feeding.

It appears that the real issue about the consent of young people under 18 is not so much rationality as rights and autonomy. That this is so can be seen from the atypical case of $T(11)$, in which the Court of Appeal overrode a 20-year-old woman's refusal of a transfusion on the grounds that she was unduly influenced by her Jehovah's Witness mother: that is, she was insufficiently autonomous - too childlike, in fact.

The Children Act is by no means a children's charter, but it appears to go too far towards allowing children autonomy for some judges. Nevertheless, it represents a long process of consultation and an unusual degree of interparty harmony. This societal consensus recognises that young people mature early - ironically, exactly the argument given for revoking the principle of doli incapax in criminal prosecutions of children.

Nor is the argument entirely naturalistic. Whether or not children and young people are maturing at an earlier age, the Act embodies a normative conviction that they should be treated as having certain rights.

A determined paternalist would simply assert that children are neither rational nor autonomous. Children do begin to develop notions of fairness and rights from an early age, about six or seven. But the paternalist might argue that children's sense of possessing rights does not give them rights - any more than C's conviction that he was an internationally renowned physician actually made him one.

The difference is that autonomy is primarily a moral 'should' rather than a factual 'is', like rationality - or being a world-famous physician. Someone is or is not rational according to a given definition, is or is not a world-famous physician. But whether or not someone is rational, we might still want to say that they should be treated as if they were self-determining. If people have rights, it is not because they pass a rationality test, and they should not lose their rights whenever they do something silly. Indeed, the High Court was making exactly this distinction in the C case - about whether a schizophrenic's rationality affected his power of selfdetermination.

Autonomy is the same for everybody. It is not an empirical concept which can be measured; it is a rule about how we treat people, and whether we accept their rights-claims. The claims of children and young people are not necessarily inferior to those of adults simply because they have not had as much experience in determining how to go about putting their values into practice and attaining their goals.

The academic lawyer John Eekelaar (12) has proposed that we should value children's autonomy separately from their rationality. In what he calls 'dynamic self-determinism', built-in periodic review gives the child and the courts a means of checking on this learning process. The goal is to reconcile the best interests of the child with the child's autonomy, with the effecting of self-determined goals.

By stating that no minor has the right to refuse consent to medical treatment, the Court of Appeal has also deflected attention from the very real probleng which can affect the expression of a child's true wishes. Developmental psychopathology shows that many situational constraints can deflect young people from their essential capacities for decision-making: attachment problems, difficult divorce and custody settlements, or child abuse and neglect. Autism and other communication disorders can also distort a child's true wishes. But if all children are lumped together as incompetent to refuse consent, there is little incentive for clinicians to make these important distinctions when appearing before the courts.

Children and young people often do not perceive that they have a choice in the first place, and therefore their rational decision-making capacities may well be underused. If children are given choices, they will be more likely to use these capacities. These abilities do depend to some extent on age, but also, crucially, on whether the child has actually been $\mathcal{N}$ given real choice and permitted to exercise it. Young $N$ people will only develop an interest in being well N informed if their choices count.

Donna Dickenson, $B A, M S c, P h D$, is a Senior Lecturer in the School of Health and Social Welfare, The Open University, Milton Keynes.

\section{References}

(1) Devereux J A, Jones D P H, Dickenson D L. Can $\frac{\rho}{\mathbb{Q}}$ children withhold consent to treatment? British 음 medical journal 1993; 306: 1459-1461.

Please turn to page 222 
remains morally relevant. See: Bleich J D. The Quinlan case: a Jewish perspective. In: Rosner F, Bleich J D, eds. Fewish bioethics. New York: Sanhedrin Press, 1979: 266-276, especially note 2: 275-276. In contrast to the Orthodox position, conservative Jewish teachings vary on this issue, believing that while withholding and withdrawing medical therapies are morally different, it may be justifiable to withdraw life-sustaining medical therapies in certain instances. See: Dorf E N. A Jewish approach to end-stage medical care. Conservative fudaism 1991; 43: 3-51, especially pages 32-33.

(6) Nozick R. Anarchy, state, and Utopia. New York: Basic Books, 1975: 150-155.

(7) Rawls's difference principle states that an increment in resources for the well-off is only just if it also results in an increase in resources for the least well-off. Under the zero-sum conditions of this case, a gain for one side entails a loss for the other side. Therefore Rawls's difference principle is not applicable to our case. See: Rawls J. A theory of justice. Cambridge, Massachusetts: The Belknap Press of Harvard University Press, 1971: 75-83.

(8) Styron W. Sophie's choice. New York: Random House, 1979.

(9) Ashley B M, O'Rourke K D. Healthcare ethics: a theological analysis [3d ed]. St Louis, Missouri: The Catholic Healthcare Association of the United States, 1989: 384.

(10) The President's Commission. Decisions to forego lifesustaining treatments. Washington, DC: US Government Printing Office, 1983: 73-77.

\section{Continued from page 204}

response is that actual possession does not of itself determine who ought to possess.

Drs Sulmasy and Sugarman have pointed to a real dilemma in practical medical ethics. Their theoretical resolution of that dilemma, despite ingenious thought experimentation, will not, alas, convince all their readers.

\section{References}

(1) Sulmasy D, Sugarman J. Are withdrawing and withholding therapy always morally equivalent? foumal of medical ethics $1994 ; 20$ : 218-222.

(2) Harris J. Are withholding and withdrawing therapy always morally equivalent? A reply to Sulmasy an\$ Sugarman. Fournal of medical ethics 1994; 20: 223-224

\section{Continued from page 206}

(2) Re W. Weekly law reports 1992; 3: 758-782

(3) $\mathrm{Re} \mathrm{R}$. Weekly law reports 1991; 3: 592-608.

(4) Dyer C. Judges give anorexic right to court say. The Guardian 1993 Oct 26.

(5) Re C. Reported in The Independent 1993 Oct 15.

(6) C (a minor) v Director of Public Prosecutions. Reported in The Guardian 1994 Mar 30.

(7) The Children Act 1989. London: HMSO, 1989.

(8) Gillick $v$ West Norfolk and Wisbech Area Health Authority. 1986; 1 Appeal cases: 112-207.
(9) Hodgson D [letter to the editor]. The Guardian 1994 Apr 1.

(10) Dickenson D, Jones D P H. True wishes: philosophical and clinical approaches to the developing case law on consent in children. Philosophy, psychiatry and psychology 1995; 1, 4.

(11) When a patient says no. Lancet 1992; 340: 345.

(12) Eekelaar J. The interests of the child and the child's wishes. In: Alston P, ed. The best interests of the child. Oxford: Oxford University Press, 1994. 